\title{
Effects of roundups on behavior and reproduction of feral horses
}

\author{
KYLE V. HANSEN AND JEFFREY C. MOSLEY
}

\begin{abstract}
Roundups are used to maintain feral horse populations in balance with rangeland grazing capacity, but little is known about short-term and long-term effects of roundups on horses. We evaluated the effects of roundups on behavior and reproduction of feral horses. The study was conducted near Challis, Ida. during 1994-1995, and repeated near Lander, Wyo. during 1995-1996. Horses were randomly assigned to 3 different treatment groups. One group (ADOPTED) was gathered by a Bureau of Land Management roundup crew using a helicopter. These horses were removed and placed in the Adopt-A-Horse Program. The second group (SIMULATED) consisted of horses that were gathered by helicopter, but these horses evaded capture and remained in the study area after the roundup. Horses in the third group (CONTROL) were not herded by helicopter. Horse behavior was monitored in the SIMULATED and CONTROL groups before and after roundups. Behavioral variables analyzed were the percentage of time spent resting, feeding, vigilant, traveling, and engaged in agonistic encounters. Neither foraging or social behavior of feral horses was affected by roundups in either study area $(P>0.10)$. Reproduction was monitored within the SIMULATED, CONTROL, and ADOPTED groups during the year following roundups. The percentages of mares with live foals did not differ $(P>0.10)$ among the 3 treatment groups in Idaho or Wyoming. Foaling success rates in Idaho were $29 \%, 31 \%$, and $43 \%$ for CONTROL, ADOPTED, and SIMULATED mares, respectively. In Wyoming, foaling success rates were $29 \%, 42 \%$, and $48 \%$ for CONTROL, ADOPTED, and SIMULATED groups, respectively. We found no evidence that roundups had deleterious effects on behavior or reproduction of feral horses.
\end{abstract}

Key Words: wild horses, Equus caballus, Adopt-A-Horse Program, foraging behavior, social behavior

About 46,000 feral horses (Equus caballus) live in the western United States (USDI-BLM and USDA-FS 1993). The Wild FreeRoaming Horse and Burro Act, Public Law 92-195 (U.S. Code 1988), obligates the Bureau of Land Management (BLM) and the U.S. Forest Service to protect feral horses on public lands of the western United States from unauthorized capture or killing. These agencies must also maintain these populations in balance with rangeland carrying capacity (USDI-BLM and USDA-FS 1993). Uncontrolled horse populations lead to excessive grazing, in turn

Authors wish to thank Kendall Johnson, Gordon Woods, Carl Hunt, and BLM personnel in Idaho and Wyoming, in particular Mike Courtney, Roy Packer, and Phyllis Stark, for their assistance.

Manuscript accepted 5 Dec. 1999.
Resumen

Las redadas se utilizan para mantener las poblaciones de caballos silvestres en balance con la capacidad de apacentamiento, pero poco se sabe acerca de los efectos a corto y largo plazo de las redadas en los caballos. Evaluamos el efecto de las redada en el comportamiento y reproducción de los caballos silvestres. El estudio se condujo cerca de Challis, Ida. durante 1994 y 1995 y se repitió cerca de Lander Wyo. durante 1995 y 1996. Los caballos se asignaron aleatoriamente a tres grupos de tratamiento. Un grupo (ADOPTADO) fue reunido y removido por una cuadrilla de redadas del Buro de Manejo de Tierras la cual utilizó un helicóptero. Estos caballos fueron después colocados en el programa "Adopta un Caballo". El segundo grupo, (SIMULADO) consistio de caballos que fueron reunidos con helicóptero, pero estos caballos evadieron la captura y permanecieron en el área de estudio después de la redada. El tercer grupo (CONTROL), fueron caballos que no se pastorearon con helicóptero. El comportamiento de los caballos se monitoreo en los grupos SIMULADO y CONTROL antes y después de las redadas. Las variables de comportamiento se analizadas fueron el porcentaje de tiempo utilizado en descanso, alimentación, vigilancia, viajar, y encuentros agonísticos. Las redadas no afectaron ni el comportamiento de alimentación ni el comportamiento social de los caballos salvajes en el área de studio $(P>0.01)$. Al año siguiente de las redadas se monitoreo la reproducción dentro de los grupos SIMULADO, CONTROL y ADOPTADOS. EI porcentaje de yeguas con potros vivos no difirió entre los tres tratamientos (P>0.10) y los resultados fueron similares en Idaho y Wyoming. Las tasas de potros vivos en Idaho fueron $29 \%, 31 \%$ y $43 \%$ para los tratamientos CONTROL, ADOPTADO y SIMULADO respectivamente. En Wyoming los porcentajes de potros vivos fueron $29 \%, 42 \%$ y $48 \%$ para lostratamientos CONTROL, ADOPTADO y SIMULADO respectivamente. No encontramos evidencia de que las redadas tuvieran un efecto nocivo en el comportamiento o la reproducción de los caballos salvajes.

causing rangeland degradation (Smith 1986). Roundups remove excess animals, after which horses are placed in private ownership via the Adopt-A-Horse Program. Roundups obviously disturb the daily routine and behavior of feral horses, but little is known about short-term and long-term effects of roundups on horses. When perturbations occur, horses may shift their behavior to minimize the effects. For example, feral horses alter their habitat use to seek refuge from biting insects (Keiper and Berger 1982). Behavioral responses to perturbations also may include increased time spent in agonistic encounters with other horses, such as when mares enter new areas and encounter resident mares (Tyler 1972). Perturbations may also induce stress that decreases 
reproduction. For example, forced copulation by invading males may induce abortion in females unprotected by their resident stallion (Berger 1983), and abortions may occur in response to male harassment or other stresses imposed by changes in a herd's social structure (Berger 1983). The purpose of this study was to document the effects of roundups on the foraging behavior, social behavior, and reproductive success of feral horses. Our specific null hypotheses were: 1) behavior does not differ between horses rounded up and horses not rounded up; and 2) reproductive success does not differ among horses rounded up, horses not rounded up, and horses placed in the Adopt-A-Horse Program.

\section{Study Area}

The study was conducted in 2 separate areas, one in central Idaho about $3 \mathrm{~km}$ southwest of Challis, Ida., and one in central Wyoming about $32 \mathrm{~km}$ north of Jeffrey City, Wyo.

\section{Idaho Study Area}

The Idaho study area was $150-\mathrm{km}^{2}$ of public land administered by the BLM, located north of Spar Canyon Road, east of State Highway 75, and west of U.S. Highway 93. Elevations ranged from 1,675-2,745 m. Annual precipitation averages $18 \mathrm{~cm}$, with about $50 \%$ occurring as snow during November through March (Perrich 1992). Major plant species present were bluebunch wheatgrass (Agropyron spicatum (Pursh.) Scribn. \& Smith), western wheatgrass (Agropyron smithii Rydb.), Sandberg bluegrass (Poa sandbergii Vasey), Idaho fescue (Festuca idahoensis Elmer), and Wyoming big sagebrush (Artemesia tridentata wyomin gensis Beetle \& Young). Limber pine (Pinus flexilus James), Douglas-fir (Pseudotsuga menziesii (Mirb.) Franco) and curlleaf mountain mahogany (Cercocarpus ledifolius Nutt. ex. Torr. \& Gray) occurred at higher elevations within the study area.

Soils ranged from a loamy-skeletal, mixed frigid Xerollic Haplargid (Dawtonia) at the lower elevations to a loamy skeletal, mixed Calcic Cryoborol (Gany) at the highest elevations. The dominant range site for the study area was Gravelly Loamy (20-30 cm precipitation) with associated range sites of Gravelly Loam (33-40 $\mathrm{cm}$ precipitation) and Flagstone (20-28 cm precipitation). The habitat type was Wyoming big sagebrush/bluebunch wheatgrass at lower ele- vations and Douglas-fir/Idaho fescue at the highest elevations (BLM-SCS 1979).

\section{Wyoming Study Area}

The Wyoming study area was in Muskrat Basin, 202-km² of public land administered by the BLM, located between State Highways 789 and 136 . Vegetation was dominated by Wyoming big sagebrush, bluebunch wheatgrass, western wheatgrass, Sandberg bluegrass, Idaho fescue, and needle-and-thread grass (Stipa comata Trin. \& Rupr.). Elevations ranged from 1,820-2,100 m. Annual precipitation averages $25 \mathrm{~cm}$ with about $50 \%$ occurring during May and June, and 50\% occurring during November through March in the form of snow (Perrich 1992). Soils were a loamy-skeletal, mixed (calcareous), frigid, shallow Ustic Torriorthent (Cragosen) in most of the area, and a fine, montmorillonitic Borollic Paleargid (Milren) on the lower sites.

The dominant range site for this study area was Loamy (24-35 cm precipitation) with associated range sites of Shallow Sandy (24-35 cm precipitation) and Sandy (25-35 cm precipitation) (Soil Conservation Service 1988).

\section{Methods}

This experiment was conducted in Idaho from July 1994 to July 1995 and in Wyoming from July 1995 to July 1996. Field procedures and statistical methods were identical for both study areas.

\section{Roundups}

Horses in each study area were randomly assigned to 3 different treatment groups. One group (ADOPTED) was gathered by a BLM roundup crew using a helicopter. These horses were removed and placed in the Adopt-A-Horse Program. The second group (SIMULATED) consisted of horses that were gathered by helicopter, but these horses evaded capture and remained in the study area after the roundup. Horses in the third group (CONTROL) were not herded by helicopter. In the Idaho study area, the ADOPTED, SIMULATED, and CONTROL groups were composed of 12, 3, and 4 bands (i.e., social subgroups) of horses, respectively. The number of bands in the ADOPTED, SIMULATED and CONTROL groups in Wyoming were 10 , 8 , and 5 , respectively. Bands contained 2 to 10 adult horses, and all bands were photographed to document their membership. Individual members of each band were also photographed, and physical character- istics of each horse were recorded to aid their identification. In Idaho, the SIMULATED, CONTROL, and ADOPTED groups totaled 14, 14, and 39 mares, respectively. In Wyoming, there were 33, 14 , and 34 mares, respectively, in the SIMULATED, CONTROL, and ADOPTED groups. In each study area the roundup and simulated roundup occurred the same day, on 27 August 1994 in the Idaho study area and 13 August 1995 in Wyoming.

\section{Horse Behavior}

Horse behavior was monitored in the SIMULATED and CONTROL groups for 3 weeks immediately before and 3 weeks after the simulated roundups. Monitoring before the simulated roundup occurred from 25 July through 26 August 1994 on the Idaho study area and 10 July through 12 August 1995 for the Wyoming area. Data following the simulated roundup was collected from 28 August through 20 September 1994 for the Idaho area and 14 August through 28 August 1995 for the Wyoming area. Behavioral observations spanned more than 600 hours during each year of the study.

We recorded the percentage of time that a band of horses spent in the following activities: feeding (primarily grazing with little or no travel other than to move to a new feeding station); resting (both recumbent and standing); traveling (including incidental grazing while walking); aggression within the band (defined as threat postures, striking with the feet, or biting); aggression between bands; and vigilance (head and neck erect, ears forward, actively looking around). Data were recorded every 10 minutes during 4-hour observation periods using instantaneous scan sampling (Altmann 1974). Each band of horses was observed 3 times before and 3 times after the simulated roundups, with one of the 3 observation periods each occurring in early morning (0700-1100 hours), mid-day (1100-1500 hours), and early evening (1500-1900 hours).

\section{Reproduction}

Adopted Groups. A veterinarian drew 10 $\mathrm{ml}$ of blood from each mare in the ADOPTED groups. These $10-\mathrm{ml}$ samples were immediately frozen, and later in the laboratory blood serum was separated from plasma. Blood serum samples were then sent to the Veterinary School at the University of California-Davis for analysis. Mares were considered pregnant if estrogen blood serum levels were $7 \mathrm{ng} / \mathrm{ml}$ or greater and progesterone levels were 6 $\mathrm{ng} / \mathrm{ml}$ or greater. In July of the year fol- 
lowing roundups, each adopter of a mare was sent a questionnaire asking for foaling information. Non-respondents were contacted in a follow-up survey by telephone. A $100 \%$ response rate was achieved.

Simulated and Control Groups. Horses in the SIMULATED and CONTROL groups were observed about 10 months after the roundups. The number of mares and foals in each band was counted on 30 June and 1 July 1995 on the Idaho site and 1 July through 5 July 1996 on the Wyoming site.

\section{Statistical Analysis}

A completely random experimental design was used. Data from the Idaho and Wyoming sites were analyzed separately. All differences were considered significant at $\mathrm{P} \leq 0.10$. For the behavioral data, a band of horses was the experimental unit. Individual horses within the bands were subsamples. Behavioral data were transformed using arcsine transformation to meet conditions for normality. Each behavioral variable (feeding, resting, traveling, aggression within the band, aggression between bands, and vigilance) was analyzed using analysis of covariance (Johnson and Wichern 1992). Observations collected before the simulated roundups were the covariables (e.g., vigilance before the simulated roundups was the covariable when analyzing vigilance after the simulated roundups). Data were then analyzed collectively using multivariate analyses. Data from the Wyoming site were analyzed using multivariate analysis of covariance (MANCO$\mathrm{VA}$ ). Dependent variables in the MANCOVA were the behavioral variables vigilance, feeding, traveling, resting, and aggression between bands following the simulated roundup. The independent variable used was group (i.e., SIMULATED or CONTROL). Covariables used were vigilance, feeding, traveling, resting and aggression between bands before the simulated roundup. For the Idaho site there were too few degrees of freedom to allow the observations before the simulated roundup to be used as covariables, so these data were analyzed using multivariate analysis of variance. Aggression within the band was not used as a variable or covariable in the multivariate analyses because no agonistic encounters within bands were recorded.

The percentage of mares with live foals in the SIMULATED, CONTROL, and ADOPTED groups was compared with chi-square analysis (Johnson and Wichern 1992).

Table 1. Mean percentage $( \pm \mathrm{SE})$ of time that bands of feral horses spent in each behavioral activity following simulated roundups.

\begin{tabular}{|c|c|c|c|c|}
\hline \multirow[b]{2}{*}{ Activity } & \multicolumn{2}{|c|}{ Idaho Site } & \multicolumn{2}{|c|}{ Wyoming Site } \\
\hline & Simulated & Control & Simulated & Control \\
\hline & $-\ldots-\ldots$ & $-\ldots-\ldots$ & $--\ldots-\ldots$ & $-\ldots-\ldots$ \\
\hline Vigilance & $12.9 \pm 0.8 \mathrm{a}^{1}$ & $8.3 \pm 0.4 a$ & $1.3 \pm 0.7 \mathrm{a}$ & $1.8 \pm 0.9 \mathrm{a}$ \\
\hline Feeding & $58.5 \pm 17.3 \mathrm{a}$ & $71.4 \pm 9.4 \mathrm{a}$ & $46.9 \pm 5.9 a$ & $38.0 \pm 5.3 a$ \\
\hline Traveling & $24.0 \pm 17.0 \mathrm{a}$ & $17.4 \pm 10.1 \mathrm{a}$ & $5.5 \pm 1.7 \mathrm{a}$ & $18.7 \pm 3.8 \mathrm{a}$ \\
\hline Resting & $4.6 \pm 3.0 \mathrm{a}$ & $2.9 \pm 2.0 \mathrm{a}$ & $46.1 \pm 6.4 \mathrm{a}$ & $41.3 \pm 0.1 \mathrm{a}$ \\
\hline Aggression within bands & $0.0 \pm 0.0 \mathrm{a}$ & $0.0 \pm 0.0 \mathrm{a}$ & $0.0 \pm 0.0 \mathrm{a}$ & $0.0 \pm 0.0 \mathrm{a}$ \\
\hline Aggression between bands & $0.0 \pm 0.0 \mathrm{a}$ & $0.0 \pm 0.0 \mathrm{a}$ & $0.1 \pm 0.0 \mathrm{a}$ & $0.2 \pm 0.0 \mathrm{a}$ \\
\hline
\end{tabular}

${ }^{\mathrm{T}}$ Within each study area, values within rows followed by the same lowercase letter are not different $(\mathrm{P}>0.10)$.

\section{Results}

\section{Horse Behavior}

Individually, none of the behavioral variables differed between SIMULATED and CONTROL treatments in either study area (Table 1). Multivariate analyses also found no differences between the SIMULATED and CONTROL groups in either the Idaho study area $(\mathrm{P}=0.67)$ or the Wyoming study area $(\mathrm{P}=0.58)$.

\section{Reproduction}

The percentage of mares with live foals did not differ $(\mathrm{P}>0.10)$ among the 3 treatments in either study area. By July 1995 in the Idaho study area, $29 \%, 31 \%$, and $43 \%$ of the mares had live foals in the CONTROL, ADOPTED, and SIMULATED groups, respectively. In the Wyoming study area, by July 1996 the percentage of mares with live foals in the CONTROL, ADOPTED, and SIMULATED groups was $29 \%, 42 \%$, and $48 \%$, respectively.

At the time of roundup, 27 of 39 mares $(69 \%)$ were pregnant in the Idaho ADOPTED group, and 18 of 34 mares $(53 \%)$ were pregnant in the Wyoming ADOPTED group. Successful pregnancies numbered 12 of $27(44 \%)$ and 14 of 18 (77\%) for Idaho and Wyoming ADOPTED groups, respectively.

\section{Discussion and Conclusions}

Roundups did not increase agonistic behavior among feral horses, nor did roundups cause feral horses to reallocate their time spent in various daily activities. Feral horses in our study allocated their time similarly to undisturbed free-roaming horses in southern France (Duncan 1980), western Alberta (Salter and Hudson 1979), and central Wyoming (Crane et al. 1997). Feeding was the primary activity.

Domestic horses are usually able to maintain their pregnancies despite hor- monal changes induced by stressful conditions (Traub-Dargatz et al. 1988, Baucus et al. 1990a, 1990b, Colburn et al. 1991, Ferlazzo et al. 1991, Wong et al. 1992). Similarly, in our study roundups did not decrease reproductive rates of feral horses. Foaling rates of the SIMULATED, CONTROL, and ADOPTED mares all compared favorably with a 10-year average of $35 \%$ documented within a feral horse herd in Montana (Garrott and Taylor 1990). The ADOPTED mares experienced the most perturbation but had an overall foaling rate of $33 \%$.

Feral horses in our study apparently adapted easily to any stress caused by roundups. We found no evidence that roundups had deleterious effects on behavior or reproduction of feral horses.

\section{Literature Cited}

Altmann, J. 1974. Observational study of behavior: Sampling methods. Behav. 49:227-265.

Baucus, K.L., S.L. Ralston, C.F. Nockels, A.O. McKinnon, and E.L. Squires. 1990a. Effects of transportation on early embryonic death in mares. J. Anim. Sci. 68:345-351.

Baucus, K.L., E.L. Squires, S.L. Ralston, A.O. McKinnon, and T.M. Nett. 1990b. Effects of transportation on the estrous cycle and concentrations of hormones in mares. J. Anim. Sci. 68:419-426.

Berger, J. 1983. Induced abortion and social factors in wild horses. Nature 303:59-61.

BLM-SCS (Bureau of Land Management-Soil Conservation Service). 1979. Range site descriptions. B12. March 1979. Internal, Boise,Ida.

Colburn, D.R., D.L. Thompson, Jr., T.L. Roth, J.S. Capehart, and K.L. White. 1991. Responses of cortisol and prolactin to sexual excitement and stress in stallions and geldings. J. Anim. Sci. 69:2556-2562.

Crane, K.K., M.A. Smith, and D. Reynolds. 1997. Habitat selection patterns of feral horses in south central Wyoming. J. Range Manage. 50:374-380.

Duncan, P. 1980. Time budgets of Camargue horses. II. Time budgets of adult horses and weaned sub-adults. Behavior 72:26-49. 
Ferlazzo, A.M., R. Vinci, M. Panzera, A. Ferlazzo, and A. Calatroni. 1991. Glycosaminoglyan concentrations in horse plasma and serum. Differences with other animal species and identification of affecting factors. Biol. Comp. Biochem. 100b:4:745-751.

Garrott, R.A., and L. Taylor. 1990. Dynamics of a feral horse population in Montana. J. Wildl. Manage. 54:603-612

Johnson, R.A., and D.A. Wichern. 1992. Applied multivariate statistical analysis. Prentice Hall, Englewood Cliffs, N.J.

Keiper, R., and J. Berger. 1982. Refuge-seeking and pest avoidance by feral horses in desert and island environments. Appl. Anim. Ethol. 9:111-120

Perrich, J.R. 1992. The ESE national precipitation databook. Cahner's Publishing Co., New York.
Salter, R.E., and R.J. Hudson. 1979. Feeding ecology of feral horses in western Alberta. J. Range Manage. 32:221-225.

Soil Conservation Service. 1988. Technical guide, section IIB major land resource area (34) Range site descriptions. USDA-SCS-WY. Cheyenne, Wyo.

Smith, M.A. 1986. Impacts of feral horses grazing on rangelands: An overview. J. Equine Vet. Sci. 6:236-238.

Traub-Dargatz, J.L., A.O. McKinnon, W.J. Bruyninckx, M.A. Thrall, R.L. Jones, and B. Blancquaert. 1988. Effects of transportation stress on bronchoalveolor lavage fluid analysis in female horses. Amer. J. Vet. Res. 49:1026-1029.
Tyler, S.J. 1972. The behaviour and social organization of the New Forest ponies. Anim. Behav. Mono. 5:85-196.

US Code. 1988. Title 16 sec. 1331 Dec. 15, 1961 Public law 92-195, 85 STAT. 649. U.S. Code. Washington, D.C.

USDI-BLM and USDA-FS. 1993. Ninth report to Congress on the administration of the Wild Free-Roaming Horse and Burro Act. Bureau of Land Management, Washington, D.C.

Wong, C.W., S.E. Smith, Y.H. Thong, J.P. Opdebeeck, and J.R. Thornton. 1992. Effects of exercise stress on various immune functions in horses. Amer. J. Vet. Res. 53:1414-1417 